\title{
Pengaruh Pemaparan Medan Magnet Pada Media Mandels Yang Dimodifikasi Terhadap Pertumbuhan Dan Aktivitas Enzim Selulase Bacillus Sp.
}

\section{Effect of Magnetic Field Exposure on Modified of Media Mandels to The Growth and Activity of The Enzyme Cellulase Bacillus sp.}

\author{
Wayan Hernawati ${ }^{1}$, Sumardi $^{2}$, Rochmah Agustrina ${ }^{2}$, dan Herman Yulianto ${ }^{2}$ \\ ${ }^{1}$ Mahasiswa Jurusan Biologi - FMIPA Universitas Lampung \\ ${ }^{2}$ Dosen Jurusan Biologi - FMIPA Universitas Lampung \\ Jl. Prof. Soemantri Brodjonegoro No.1, Bandar Lampung 35145 \\ Email:sumardi_bio@yahoo.co.id
}

\begin{abstract}
Enzymes can undergo structural changes due to various environmental factor such as $\mathrm{pH}$, temperature, electricity and magnetic fields. The purpose of this study was to investigate the effect of magnetic field strength and duration of exposure to the modified of media Mandels used as a culture medium of Bacillus sp. on the growth and activity of cellulase enzyme from the bacterium Bacillus sp. Factorial study group were prepared using the method of full randomized design (RKLT). The first factor is the strong magnetic field consists of 4 levels of magnetic field strength treatment: $0 \mathrm{mT} ; 0,1 \mathrm{mT} ; 0,2 \mathrm{mT} ; 0.3 \mathrm{mT}$. The second faktor is the prolonged exposure consisting of 4 levels prolonged exposure treatments $0,10,20,30$ minutes. each unit treatment was repeated 3 times. The results showed that exposure to magnetic fields on modified of media Mandels causes a decrease in the relative activity of the enzyme cellulase and relative growth of Bacillus sp.
\end{abstract}

Keywords: cellulase enzyme, magnetic field, Mandels modification, Bacillus sp.

Diterima: 29 Desember 2015, disetujui 27 Maret 2016

\section{PENDAHULUAN}

Enzim dapat mengalami perubahan struktur karena berbagai faktor lingkungan, antara lain: $\mathrm{pH}$, suhu, aliran listrik dan juga medan magnet (Poedjadi dan Supriyanti, 2009). Medan magnet merupakan suatu medan atau area yang dipengaruhi oleh gaya magnetik yang ditimbulkan oleh arus listrik yang dialirkan pada solenoida (Maharta, 1994). Medan magnet yang diinduksikan pada proses pengolahan limbah cair diketahui dapat meningkatkan $\mathrm{pH}$ air limbah (Alkhazan and Saddiq, 2010) yang dapat mempengaruhi aktivitas enzim mikroorganisme (Poedjadi dan Supriyanti, 2009).

Salah satu pengaruh lingkungan yang banyak dipelajari saat ini adalah medan magnet. Medan magnet juga dapat menurunkan laju presipitasi partikel - partikel pada larutan $\mathrm{Na}_{2} \mathrm{CO}_{3}$ dan $\mathrm{CaCl}_{2}$ (Saksono dkk., 2007). Tujuan dari penelitian ini adalah untuk mengetahui pengaruh kuat medan magnet dan lama pemaparan pada media Mandels yang dimodifikasi dan digunakan sebagai medium pertumbuhan dan aktivitas enzim selulase dari bakteri Bacillus sp. 


\section{METODE}

Penelitian dilakukan di Laboratorium Mikrobiologi Jurusan Biologi Fakultas Matematika dan Ilmu Pengetahuan Alam, Universitas Lampung pada Bulan Januari 2015 sampai Bulan Maret 2015.

Bahan yang digunakan dalam penelitian ini adalah media Mandels yang dimodifikasi dengan komposisi: carboxymethyl-cellulose (CMC) $0,5 \%$, yeast $0,35 \%$, trypton water $0,35 \%, \mathrm{NaCl} 0,2 \%, \mathrm{KH}_{2} \mathrm{PO}_{4}$ $0,245 \%, \mathrm{MgSO}_{4} .7 \mathrm{H}_{2} \mathrm{O} 0,035 \%$, dan $\left(\mathrm{NH}_{4}\right)_{2} \mathrm{SO}_{4} 0,17 \%$.

Penelitian ini merupakan penelitian faktorial yang disusun menggunakan metode Rancangan Kelompok Lengkap Teracak (RKLT). Faktor pertama adalah kuat medan magnet terdiri dari 4 taraf perlakuan yaitu kuat medan magnet $0 \mathrm{mT}$; $0,1 \mathrm{mT}$; $0,2 \mathrm{mT}$; dan $0,3 \mathrm{mT}$. Faktor kedua adalah lama pemaparan yang terdiri dari 4 taraf perlakuan lama pemaparan yaitu 0, 10, 20, 30 menit. Masing - masing unit perlakuan diulang 3 kali. Penelitian dilakukan dengan tiga tahap uji, yaitu: uji pendahuluan, uji pengaruh medan magnet terhadap aktivitas enzim, dan penentuan pertumbuhan bakteri Bacillus sp.

\section{Uji Pendahuluan}

Uji pendahuluan dilakukan dalam bentuk pemaparan medan magnet pada media Mandels yang dimodifikasi dengan menambahkan agar padat dengan 3 cara pemaparan, yaitu 1) kontrol (tanpa pemaparan medan magnet), 2) pemaparan medan magnet pada media Mandels yang dimodifikasi dan belum diisi inokulum Bacillus sp., 3) pemaparan medan magnet pada media Mandels yang dimodifikasi dan telah di inokulasikan dengan Bacillus sp. Kuat medan magnet yang digunakan adalah sebesar 0,2 mT, dengan waktu pemaparan 5,10, dan 15 menit pada masing - masing perlakuan. Semua inokulum Bacillus sp. kemudian diinkubasi pada suhu $37^{\circ} \mathrm{C}$ selama $12 \mathrm{jam}$. Inokulum Bacillus sp. yang telah diinkubasi diwarnai dengan menggunakan congo red untuk melihat zona jernihnya.

Pada uji pendahuluan juga dilakukan penentuan waktu inkubasi optimum produksi enzim selulase Bacillus sp. pada media Mandels yang dimodifikasi. Media Mandels yang dimodifikasi dan telah disterilkan diinokulasi dengan $5 \mathrm{ml}$ starter Bacillus sp. yang berumur 18 jam. Biakan diinkubasi pada suhu $40^{\circ} \mathrm{C}$ selama $0,6,12,18,24$, dan 30 jam di dalam waterbath shaker dengan kecepatan goyangan $80 \mathrm{rpm}$. Setelah selesai diinkubasi, media kultur disentrifugasi dengan kecepatan $1000 \mathrm{rpm}$ selama 5 menit. Cairan supernatan yang terbentuk merupakan ekstrak kasar enzim selulase yang akan ditentukan aktivitasnya dengan pengukuran menggunakan spektrofotometer.

\section{Uji Pengaruh Medan Magnet Terhadap Aktivitas Enzim}

Uji pengaruh medan magnet terhadap aktivitas enzim dilakukan melalui tahapan pemaparan media produksi enzim selulase dengan medan magnet, inokulasi bakteri Bacillus sp. pada media yang sudah dipapari dengan medan magnet, ekstraksi enzim selulase dari bakteri Bacillus sp. yang telah diinkubasi, dan penentuan gula standar glukosa, Penentuan aktivitas enzim selulase dilakukan berdasarkan kadar glukosa yang dihasilkan.

Pemaparan media produksi enzim selulase dengan medan magnet dilakukan dengan menggunakan media Mandels yang dimodifikasi sebanyak $50 \mathrm{ml}$ di dalam erlenmeyer $250 \mathrm{ml}$. Media produksi kemudian diberi perlakuan pemaparan medan magnet dengan kuat medan magnet dan lama pemaparan sesuai perlakuan.

Media produksi enzim selulase (media Mandels yang dimodifikasi) yang telah diberi perlakuan pemaparan medan magnet selanjutnya diinokulasi dengan $5 \mathrm{ml}$ starter Bacillus sp yang berumur 18 jam. Biakan kemudian diinkubasi pada suhu $40^{\circ} \mathrm{C}$ selama 18 jam di dalam waterbath shaker dengan kecepatan goyangan $80 \mathrm{rpm}$. 
Ekstraksi enzim selulase dilakukan dengan cara sentrifugasi media kultur pada kecepatan 1000 rpm selama 5 menit. Cairan supernatan yang terbentuk merupakan ekstrak kasar enzim selulase yang akan ditentukan aktivitasnya. Pengujian aktivitas enzim selulase dilakukan dengan tiga tahap, yaitu: penentuan gula standar glukosa, penentuan suhu optimum inkubasi enzim selulase, uji aktivitas enzim selulase, dan perhitungan aktivitas enzim selulase.

Pada penentuan gula standar glukosa, larutan gula standar yang digunakan adalah larutan standar reduksi glukosa pada interval 0-500 $\mu \mathrm{g} / \mathrm{ml}$. Berdasarkan metode Bernfeld (1955) dalam Ekowati, dkk. (2013), gula standar glukosa ditentukan dengan cara membuat satu seri larutan glukosa standar secara berurutan dari konsentrasi $0 \mu \mathrm{g} / \mathrm{ml}, 100 \mu \mathrm{g} / \mathrm{ml}, 200 \mu \mathrm{g} / \mathrm{ml}, 300 \mu \mathrm{g} / \mathrm{ml}, 400 \mu \mathrm{g} / \mathrm{ml}, 500 \mu \mathrm{g} / \mathrm{ml}$ dalam tabung

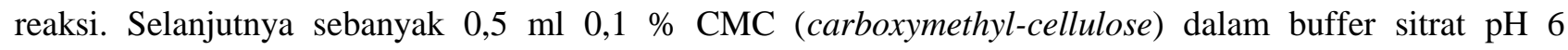
dicampur dengan 0,5 ml larutan glukosa. Ke dalam tabung reaksi kemudian ditambahkan $1 \mathrm{ml}$ larutan DNS. Campuran tersebut dipanaskan dalam air mendidih selama 15 menit. Pendinginan larutan standar dilakukan dalam air dingin selama 20 menit sebelum dibaca absorbansinya dengan spektrofotometer pada panjang gelombang $575 \mathrm{~nm}$.

Penentuan aktivitas enzim selulase dilakukan berdasarkan kadar glukosa yang dihasilkan. Kadar glukosa diukur dengan menggunakan metode DNS (Miller, 1995 dalam Ekowati, dkk. 2013). Supernatan diambil sebanyak 0,5 ml, kemudian dicampurkan dalam tabung sampel dengan CMC 0,5\% dalam buffer sitrat sebanyak $0,5 \mathrm{ml}$ dan dinkubasi selama 30 menit pada suhu $40^{\circ} \mathrm{C}$. Sebagai kontrol digunakan campuran enzim dan larutan CMC 0,5\% yang langsung dipanaskan tanpa diinkubasi selama30 menit. Kedalam tabung kontrol ditambahkan1ml 3,5- dinitrosaliclicacid. Semua tabung sampel dihomogenkan dan dipanaskan dalam air mendidih selama15 menit. Tabung sampel kemudian didinginkan dengan air dingin selama 20 menit selanjutnya diukur absorbansinya menggunakan spektrofotometer pada panjanggelombang $575 \mathrm{~nm}$. Nilai absorbansi yang diperoleh, akan digunakan untuk menghitung aktivitas enzim selulase. Aktivitas enzim selulase didapatkan dengan perhitungan menggunakan rumus sebagai berikut:

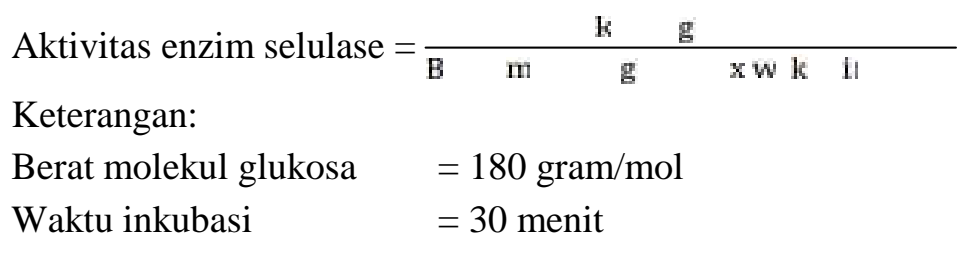

\section{Penentuan Pertumbuhan Bakteri Bacillus sp.}

Penentuan pertumbuhan bakteri selulolitik dilakukan dengan menghitung jumlah koloni bakteri yang menghasilkan zona jernih di sekitar koloni menggunakan metode pour plate. Sebanyak $1 \mathrm{ml}$ isolate Bacillus sp pada media Mandels yang dimodifikasi divortex selama $1-2$ menit lalu dimasukkan kedalam garam fisiologis $9 \mathrm{ml}$ (pengenceran $10^{-1}$ ). Kemudian satu $\mathrm{ml}$ suspensi dari pengenceran dipindahkan $10^{-1}$ menggunakan micropipette ke dalam tabung reaksi yang berisi $9 \mathrm{ml}$ garam fisiologis steril sehingga didapatkan pengenceran $10^{-2}$ dan dengan cara yang sama dilakukan hingga pengenceran $10^{-14}$.

Sebanyak $1 \mathrm{ml}$ suspense dari seri pengenceran $10^{-13}$ dan $10^{-14}$ masing-masing dimasukkan ke dalam cawan petri steril, kemudian ditambahkan media Mendel yang dimodifikasi dengan menambahkan agar padat dan dibiarkan hingga padat. Setelah media padat, diinkubasi selama 24 jam pada suhu $37^{\circ} \mathrm{C}$. Setelah masa inkubasi berakhir, kultur bakteri ditetesi larutan congored $0,1 \%$. Koloni-koloni yang membentuk zona jernih menunjukkan adanya aktivitas bakteri selulolitik. Koloni yang membentuk zona jernih kemudian dihitung dengan menggunakan colony counter.

Pengambilan data berupa jumlah koloni dan aktivitas enzim selulase yang diperoleh dari assay menggunakan spektrofotometer setelah Bacillus sp. diinkubasi selama 18 jam. 


\section{HASIL DAN PEMBAHASAN}

\section{Uji Pendahuluan}

Perlakuan yang menghasilkan pertumbuhan koloni dan zona jernih yang paling luas adalah pemaparan medan magnet pada media Mandels yang dimodifikasi dan belum diinokulasi inokulum Bacillus sp. (Gambar. 1).

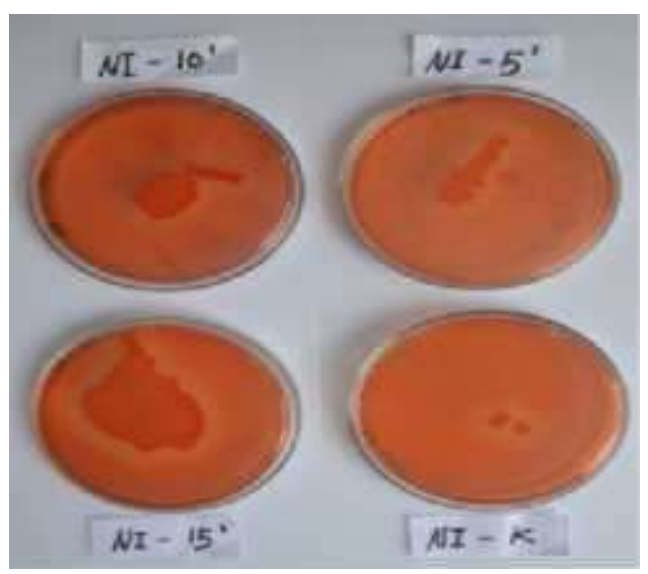

Gambar 1. Hasil uji pendahuluan zona jernih pada media CMC-agar dengan pemaparan medan magnet sebelum diinokulasi inokulum Bacillus sp.

Hasil penelitian menunjukkan pada kondisi normal (tanpa pemaparan medan magnet), inkubasi Bacillus sp. selama 18 jam memberikan aktivitas enzim selulase yang paling tinggi yaitu: 0,037 U/ml (Gambar. 2).

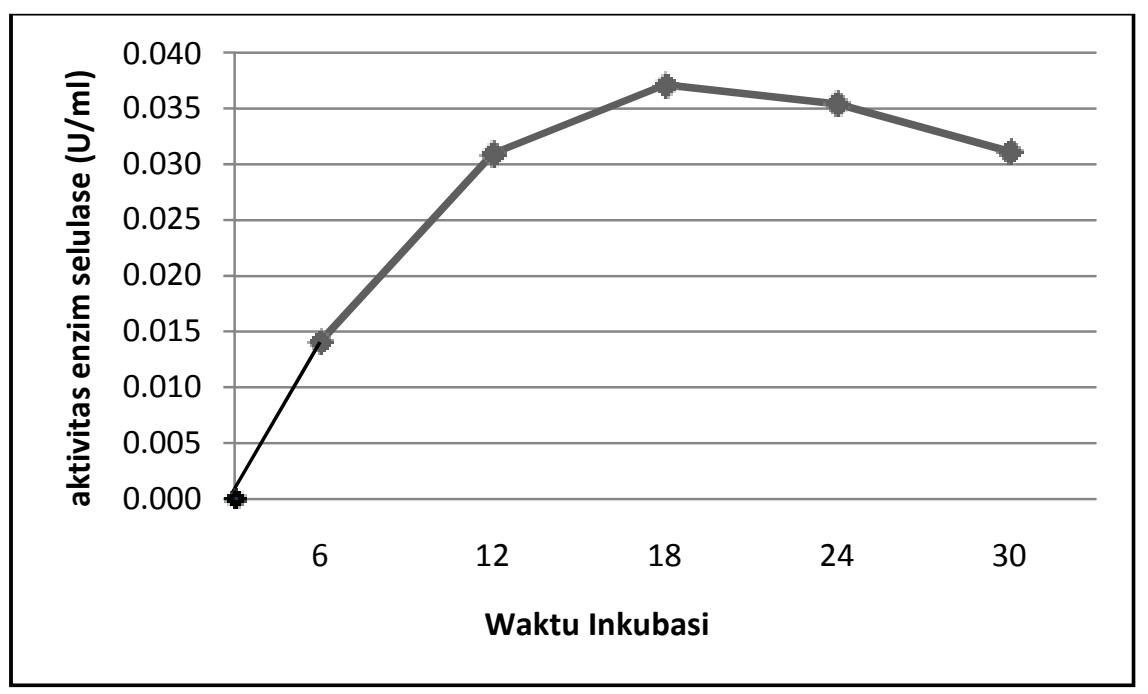

Gambar 2. Waktu inkubasi optimum Bacillus sp. pada media modifikasi Mandels

Tingginya aktivitas enzim selulase Bacillus sp. pada waktu inkubasi 18 jam, diduga karena pertumbuhan bakteri masih berada pada fase eksponensial atau fase logaritma, berarti aktivitas relatif enzimnya pun sangat tinggi. 
Wayan dkk : Pengaruh Pemaparan Medan Magnet Pada Media Mandels Yang Dimodifikasi Terhadap Pertumbuhan ...

\section{Uji Pengaruh Medan Magnet}

Perubahan medan magnet pada Bacillus sp. Akan menghasilkan respon aktivitas relatif enzim selulase yang fluktuatif (Gambar 3). Pemaparan dengan kuat medan magnet 0,2 $\mathrm{mT}$ menghasilkan aktivitas relatif enzim selulase dan pertumbuhan relatif yang paling rendah dibandingkan dengan kontrol akan tetapi perlakuan pemaparan kuat medan magnet $0,3 \mathrm{mT}$ kembali meningkatkan aktivitas relatif enzim selulase Bacillus sp.

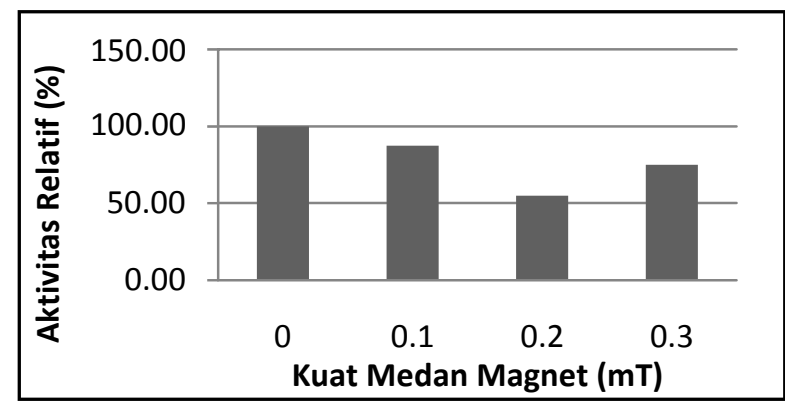

Gambar 3. Pengaruh kuat medan magnet terhadap aktivitas relatif enzim selulase Bacillus sp.

Hasil penelitian pada Gambar 4, juga menunjukkan bahwa perubahan medan magnet pada Bacillus sp. tidak berpengaruh terhadap pertumbuhan relatifnya. (Gambar 4).

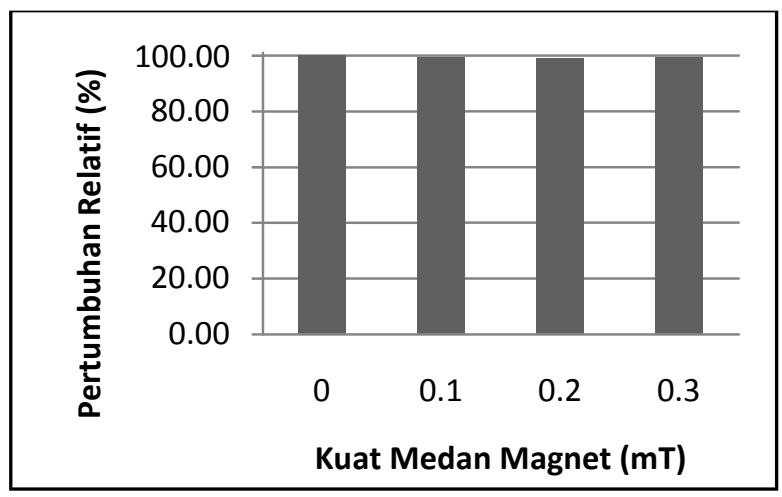

Gambar 4. Pengaruh kuat medan magnet terhadap pertumbuhan Bacillus sp.

Respon aktivitas relatif enzim selulase yang fluktuatif dalam penelitian ini diduga karena adanya pengaruh sifat -sifat kimia dari unsur - unsur yang terdapat dalam media Mandels yang dimodifikasi dan digunakan sebagai medium kultur Bacillus sp. yang memiliki elektronegativitas, energi ionisasi, dan afinitas elektron yang berbeda sehingga cenderung kurang stabil. Chang (2005) menyatakan beberapa unsur tersebut digolongkan kedalam unsur logam $(\mathrm{Na}, \mathrm{K}, \mathrm{Mg})$ dan non logam $(\mathrm{H}, \mathrm{N}, \mathrm{P}, \mathrm{O}, \mathrm{C}, \mathrm{S}, \mathrm{Cl})$ pada sistem periodik.

Ada beberapa hal yang mempengaruhi sifat - sifat kimia masing - masing unsur, yaitu: elektronegativitas, energi ionisasi dan afinitas elektron, ketiganya sangat berkaitan. Elektronegativitas adalah kemampuan suatu atom untuk menarik elektron dari atom lain dalam suatu senyawa. Keelektronegatifan suatu unsur bergantung pada nomor atom dari unsur tersebut. Keelektronegatifan unsur dalam suatu periode dan golongan pada sistem periodik akan berkurang seiring dengan bertambahnya nomor atom dan bertambahnya sifat logam dari setiap unsur. Unsur yang memiliki elektronegativitas yang tinggi dapat membentuk ikatan kovalen yang sulit diputus, contohnya magnesium (Chang, 2005). 
Chang (2005), juga menyatakan bahwa elektronegativitas suatu unsur juga dipengaruhi oleh energi ionisasi dari unsur tersebut. Energi ionisasi suatu unsur berbanding lurus dengan elektronegativitasnya, semakin elektronegatif suatu unsur maka energi yang yang diperlukan untuk melepas satu elektron akan semakin tinggi. Kestabilan elektron terluar dari suatu atom bergantung pada energi ionisasi.

Afinitas elektron juga berpengaruh pada sifat atom. Afinitas elektron adalah energi yang harus dilepaskan ketika suatu elektron ditambahkan kedalam suatu atom. Semakin besar afinitas elektron semakin stabil elektron dalam suatu atom (Chang, 2005).

Unsur - unsur di dalam media modifikasi Mandels memiliki energi ionisasi, elektronegativitas, dan afinitas elektron yang berbeda. Hal inilah yang diduga menyebabkan fluktuasi pada aktivitas enzim selulase Bacillus sp. dalam medium Mandels yang dimodifikasi dan diberi paparan medan magnet.

Pengaruh lain yang memungkinkan terjadinya respon aktivitas relatif enzim selulase Bacillus sp adalah ion logam dalam media modifikasi Mandels yang merupakan kofaktor enzim selulase. Kofaktor yang berupa ion logam berpengaruh pada proses ionisasi dan perpindahan elektron. Fessenden and Fessenden (1986) menyatakan bahwa kofaktor merupakan bagian non protein dari enzim berupa ion logam sederhana yang dapat membantu kerja enzim. Beberapa ion yang bertindak sebagai kofaktor bagi enzim tertentu dan harus ditambahkan ke dalam medium pertumbuhan adalah $\mathrm{Mg} 2+, \mathrm{Ca} 2+$, dan $\mathrm{K}+$ (Volk dan Wheeler, 1988).

Menurut Ma'rufiyanti, dkk. (2014), pemaparan medan magnet menyebabkan perpindahan energi dari medan magnet ke ion-ion di dalam tubuh bakteri maupun ion yang ada pada lingkungan medium tumbuhnya. Sari, dkk. (2012), menjelaskan bahwa medan magnet dapat menyebabkan ionisasi beberapa garam seperti $\mathrm{Mg} 2+$ dan $\mathrm{Ca} 2+$. Magnesium merupakan materi yang bersifat diamagnetik (Wiyanto, 2008). Materi diamagnetik merupakan materi magnetik yang kemampuan merespon gaya magnetik (susepbilitas) materi ini tidak konstan sehingga dapat diasumsikan perpindahan energi dari medan magnet pada ion $\mathrm{Mg} 2+$ juga tidak stabil sehingga aktivitas relatif enzim selulase dan pertumbuhan Bacillus sp. menjadi tidak stabil (cenderung fluktuatif) pada medium dipapari medan magnet. Selain itu, menurut Mosinand Ignatov (2014), air yang dipaparkan medan magnet memungkinkan terjadinya perubahan $\mathrm{pH}$ dan hidrasi larutan garam.

Hasil penelitian Zhang, et al. (2011) yang menggunakan ekstrak murni enzim selulase menunjukkan bahwa kuat medan magnet 2,2 $\mathrm{mT}$ dengan pemaparan selama 20 menit mampu meningkatkan aktivitas enzim selulase namun pada kuat medan magnet 4,2 $\mathrm{mT}$ terjadi penurunan. Pada perlakuan lama pemaparan medan magnet, diperoleh hasil yang menunjukkan semakin lama perlakuan pemaparan medan magnet, maka aktivitas relatif enzim selulase cenderung semakin menurun (Gambar 3), sedangkan pertumbuhan relatif Bacillus sp. tidak terlihat berbeda (Gambar 4).

Perlakuan pemaparan medan magnet pada medium tumbuh Bacillus sp., diduga membantu mempercepat penyerapan nutrien sehingga aktivitas enzim selulase dan pertumbuhan Bacillussp. juga meningkat, akan tetapi pada waktu inkubasi lebih 18 jam kultur Bacillus sp sudah memasuki fase statis atau bahkan fase kematian karena kehabisan nutrien dalam medium tumbuhnya sehingga terjadi penurunan jumlah bakteri dan aktivitas enzim selulase.

Rohma (2013), menjelaskan bahwa medan magnet dapat meningkatkan perkecambahan biji tanaman holtikultura. Peningkatan tersebut diduga sebagai akibat adanya perubahan sifat fisik dan kimia air yang disebabkan oleh medan magnet. Air pada kecambah lebih mudah diserap sehingga mempercepat proses metabolisme biji. Matwijczuk et al. (2011), juga menyatakan bahwa pemaparan medan magnet baik pada biji bunga matahari langsung maupun pada air untuk menyiram kecambah bunga matahari dapat meningkatkan kecepatan perkecambahan.

Fijalkowski, et al. (2013), menyatakan bahwa pemaparan medan magnet pada bakteri Escherichia Coli dan Staphylococcus Aureus dengan frekuensi $1-50 \mathrm{~Hz}$ selama 60 menit pada suhu inkubasi $37{ }^{\circ} \mathrm{C}$ dapat meningkatkan pertumbuhan, aktivitas metabolisme dan kemampuan pembentukan bio-film. Hasil yang berbeda ditunjukkan dari hasil penelitian Fojt, et al. (2009) yang menyatakan bahwa pemaparan medan 
Wayan dkk : Pengaruh Pemaparan Medan Magnet Pada Media Mandels Yang Dimodifikasi Terhadap Pertumbuhan ...

magnet yang semakin lama, mengakibatkan penurunan pertumbuhan bakteri E. coli dan P. denitrificans. Namun demikian respon pertumbuhan bakteri terhadap pengaruh pemaparan medan magnet berbeda tergantung pada spesiesnya.

\section{KESIMPULAN}

Pemaparan medan magnet pada media Mandels yang dimodifikasi dan digunakan sebagai medium tumbuh Bacillus sp. akan menurunkan aktivitas relatif enzim selulase Bacillus sp. namun tidak memberikan pengaruh terhadap pertumbuhan relatif Bacillus sp.

\section{DAFTAR PUSTAKA}

Alkhazan. M.M.K. and Saddiq, A.A.N. 2010. The Effect Magnetic Field on the Physical, Chemical, and Microbiological Properties of the Lake Water in Saudi Arabia. Journal of Evolutionary Biology Research Vol 2 (1), pp. 7-14. ISSN 2141-6583.

Chang, Raymond. 2005. Konsep-Konsep Inti Edisi Ketiga Jilid 1. Erlangga. Jakarta.

Ekowati. C.N., Sumardi, dan Handayani, K. 2013. Penuntun Praktikum Fisiologi Mikroba. Biologi FMIPA Unila. Bandar Lampung.

Fessenden, R.J. and Fessenden, J.S. 1982. Kimia Organik. Penerbit Erlangga. Jakarta.

Fijalkowski. K., Narowtek. P., Struk. M., Kordas. M., and Rakoczy, R. 2013. The Effect of Rotating Magnetic Field on Growth Rate, Cell Metabolic Activity, and Biofilm Formation by Staphylococcus aureus and Escherichia coli. Szczecin, Poland. Journal of Magnetic18 (3) 289-296 (2013), ISSN 2233-6656

Fojt. L., Klapetek. P., Strasak. L., and Vetterl. V. 2009. 50 Hz Magnetic Field Effect on The Morphology of Bacteria. Czech Republic. Elsevier Ltd Micron 40 (2009) 918-922.

Maharta, N. 1994. Fisika Sistematik Jilid 1. Conceps Science, Bandung. Bandung.

Ma'rufiyanti. P., Sudarti, dan Gani. A. A. 2014. Pengaruh Pemaparan Medan Magnet ELF (Extremly low Frequency) $300 \mu$ Tdan $500 \mu$ T Terhadap Perubahan Vitamin C dan Derajat keasaman (pH) pada Buah Tomat. Jurnal Pendidikan Fisika, Vol. 3 No.3 Desember 2014, Hal 278-284.

Matwijczuk. A., Kornarzynski. K., and Pietruszewski. 2012. Effect of Magnetic Field on Seed Germination and Seedling Growth of Sunflower. Int. Agrophys., 2012, 26, 271-277. doi: 10.2478/v10247-0120039-1.

Mosin. O and Ignatov. I. 2014. Basic Concepts of Magnetic Water Treatment. European Journal of Molecular Biotechnology, ISSN: 2310-6255. Vol. 4, No. 2, pp. 72-85, 2014.

Poedjadi. A dan Supriyanti. F.M.T. 2009. Dasar - Dasar Biokimia. Universitas Indonesia. Jakarta.

Rohma, Aulia. 2013. Pengaruh Medan Magnet Terhadap Aktivitas Enzim $\alpha$-Amilase pada Kecambah Kacang Merah dan Kacang Buncis Hitam (Phaseolus vulgaris L.). Universitas Lampung. Bandar Lampung. Skripsi. 
Saksono. N., Mubarok. M.H., Widaningroem. R., dan Bismo. S. 2007. Pengaruh Medan Magnet TerhadapKonduktivitasLarutanN $\mathrm{N}_{2} \mathrm{C}_{3}$ Dan Ca $\mathrm{C}_{2}$ Serta Presipitasi Dan Morfologi Partikel CaC 3 Pada Sistem Fluida Statis. Jurnal Teknologi 317-323 ISSN 0215-1685. Universitas Indonesia. Jakarta.

Sari. E.K.N., Susilo. B., danSumarlan.S.H. 2012. Proses Pengawetan Sari Buah Apel (Mallussylvertris Mill) Secara Non Thermal Berbasis Teknologi Oscillating Magnetic Field (OMF). Jurnal Teknologi Pertanian Vol.13 No.2 (Agustus 2012) 78-87.

Wiyanto. 2008. Elektromagnetika. Graha ilmu.Yogyakarta. ISBN 978-979-756-318-9

Volk, W.A dan Wheeler, M.F. 1988. Mikrobiologi Dasar Edisi Kelima Jilid I. Erlangga. Jakarta.

Zhang. J., Wang. S., Xu. B., and Gao. M. 2011. Effect of Alternating Magnetic Field Treatments on Enzymatic Parameters of Cellulase. J. Sci Food Agric. 2012, 92: 1384-138 